\title{
Metadiscourse in Research Writing: A Study of Native English and Pakistani Research Articles
}

\author{
Haroon Shafique ${ }^{1}$, Muhammad Shahbaz ${ }^{2} \&$ Muhammad Rashid Hafeez ${ }^{2}$ \\ ${ }^{1}$ Department of English, University of Lahore, Chenab Campus, Punjab, Pakistan \\ ${ }^{2}$ Department of English, GC Women University Sialkot, Punjab, Pakistan \\ Correspondence: Dr. Muhammad Rashid Hafeez, Department of English, GC Women University, Sialkot, Punjab, \\ 51310, Pakistan. E-mail: m.rashid@gcwus.edu.pk
}

Received: April 2, 2019 Accepted: April 26, 2019 Online Published: July 17, 2019

doi:10.5539/ijel.v9n4p376 URL: https://doi.org/10.5539/ijel.v9n4p376

\begin{abstract}
Metadiscourse is extremely important for structuring a relationship between writer and reader when it comes to academic writing. It is an interesting area of inquiry that is believed to play a vital role in writing persuasive discourse, based on the expectations of the people involved (Behzad \& Shafique, 2018). This study deals with the comparative analysis of native English and Pakistani research articles. For this research, 100 native English and Pakistani English research articles are taken, following Hyland and Tse (2004a) model of metadiscourse. A corpus-based mixed method research approach is employed to carry out this study. All the metadiscursive devices are quantified by using corpus-based approach and then analyzed qualitatively. The results reveal that Pakistani research writers use more interactive markers whereas the interactional markers are found frequent in native English academic writers. The overall results disclose that Native research writers of English are more persuasive in their research writing as they guide the readers through text as well as involve them through different markers effectively.
\end{abstract}

Keywords: metadiscourse, interactive metadiscourse, interactional metadiscourse

\section{Introduction}

Metadiscourse, the term was first devised by Zelling in 1959 which later on was much more elaborated by many researchers like (as cited in Shafique, 2016; Williams, 1981; Sciffrin, 1994; Crismore, 1989; Halliday, 1994; Hyland, 2005). In areas of language education and discourse analysis, metadiscourse is a new and interesting approach about conceptualizing interactions between producers of texts and their texts as well as between users and producers of texts (Hyland, 2010). It is a way to analyze the language in use as a means of communication and social interaction. It assists us to see the relationship between the language choices we make when we communicate and the social contexts (Halliday, 1994). It represents the speaker's attempt to guide the receiver's perception towards a text.

Metadiscourse is actually a fuzzy and complex term which focuses on discourse about any discourse, text beyond a particular text and talk about a specific talk. Metadiscourse provides dissatisfactory views about inclusion of various features of language that guide the organization of ideas by a producer of text to relate ourselves to readers. Beauvais (1989) defines metadiscourse as the overt markers which help the listeners to identify how the arguments of a speaker are to be understood. For Lautamatti (1978), metadiscourse is an unconventional linguistic material which seems inappropriate to discourse topic development, but it is the key to understand discourse as a whole (Shahbaz et al., 2013). Metadiscourse for Hyland (2005b) is an attractive concept which offers, one heading, various strategies for the writers to shape their texts and involve the readers along with revealing their attitude to material as well as addressees.

Metadiscourse, therefore is a vital and significant link between a text and its context because it points to the reader's expectations for certain forms of interaction and engagement. It brings into light the dialogic character of discourse by spotlighting authors' knowledge of his/her audience through the choice of words he uses to address his/her readers and their varying needs. These expectations are communal, affective, social and cognitive based upon the beliefs and values of the participants, their individual goals and expectations with similar texts in the past. Therefore, a text should approach the receivers/readers in such a manner that they find it assessible and 
acceptable, which in turn highlight that the processes of participation and comprehension are not simply a matter of informational lucidity, but of the individual speaker/author's projection of a shared context. According to Hyland (2005b), metadiscourse offers autonomy to speakers and writers to develop their positions and bring themselves in line with their readers. The idea collects different forms of text commentary to show how speakers and writers intervene into their unfolding texts to influence the receiver's perception towards the text. Basically, metadiscourse embodies that communication is not merely exchange of information, services or goods, but also involves personalities, assumptions and attitudes of the interlocutors. Language is always a part of communication but the differences between the people are also there while communication and metadiscourse gives insight to the ways to articulate and construct these interactions. It stresses the fact that whatever we speak or write, we negotiate with the people we speak or to the people we write and make decisions about the effects our speech has on our listeners or readers. It is the writer's explicit or implicit presence in the discourse in order to direct the receivers. It also gives insight to the linguistic material given to the readers to see what the readers understand and what is meant by primary discourse. Metadiscourse reveals author's or speaker's awareness of his listeners/readers and his/her need for interaction, guidance, elaboration and clarification. While expressing their awareness of the text, the writers/speakers also develop this awareness among listeners/readers, and this can only happen if they have a strong reader-oriented reason for doing so.

\section{Research Questions}

- What metadiscourse markers are preferred by Native and Pakistani English research writers?

- How differently Native English and Pakistani research writers use metadiscourse markers?

- Which of the both writers are more persuasive in their article writing?

\section{Literature Review}

According to Flowerdew (1999), the domination of the English in academia has pushed scholars/researchers to get their valuable research works published in international English databases. This tendency has led the writers to pay a great deal of attention for mastering the art of manuscript writing for publication in a clear and concise language for the global readers. The EFL students find the mastery this task more demanding as well as significant as compared to oral skills (Abdi, 2011; Shahbaz \& Liu, 2012). In fact, research writing can be considered as a process of knowledge transformation that is employed by writers to develop clarity, understanding and value to their works for the potential readers (Gray, 2000). Thus, this process of research writing becomes more than merely the selection of linguistic symbols where socio-political factors impact the writers who, being the owners of power, work hard for the recognition and acknowledgment of the community they write for (Casanave, 2003). Therefore, mindfulness about the conventions and rules benefits the writers to convey their ideas in a persuasive and effective manner. As a result, there is good deal of emphasis on different features of article writing in the last few years. There are many studies in which the use of interaction markers is compared in a particular area of multiple languages. Some researchers have dedicated their time to the assessment of interaction markers in various genres of a particular language. Interaction markers have gained considerable attention in area of research writing as a major rhetoric effect which influences the communicative ability of the writers. Conversely, the idiosyncratic features of interaction markers have made this possible for various research to explore them in different languages e.g. French- Norwegian (Breivega, 2002), SpanishEnglish (Valero 1996), Finish- English (Mauranan, 1993), English-Persian (Taki, 2012), English-Arabic (Sultan, 2011), English-Bulgarian (Vassileva, 2001) to highlight the variances in the application of interaction markers in research writings.

In another research work, the interaction markers were analyzed by Abdollazadeh (2003) where he selected sixty-five articles by native and Iranian writers and analyzed discussion and conclusion parts of research writings published from 2000-2002 in areas of linguistics and applied linguistics. The results highlighted significantly higher usage of interaction markers by native writers compared to Iranian writers. Moreover, the use of boosters and attitude markers had significant difference and thus had higher frequency in the research articles of Anglo-American writers. Rahimpour (2006) investigated the interaction markers and their application in discussion sections of ninety research papers in the field of applied linguistics. He took 30 research works in English from British and American writers, 30 papers in English written by Iranian writers and 30 researches published in Persian by Iranian writers. Hence, three groups were analyzed. Hylands' (2004) typology of metadiscourse was applied to the discussion sessions of the research articles to see the metadiscourse features. The results suggested that the native speakers of English use interaction markers more significantly as compared to the other group of Iranian writers of English and Persian (YES or NO).

Other researchers (Shokouhi \& Baghsiahi, 2009) studied interaction markers in Persian and English papers from 
the field of sociology. Ten articles were randomly selected from the consultation of academic professionals belonging to sociology department. The articles were taken from renowned journals of sociology written in English language and Persian articles were taken in the same way. The results showed the higher frequency of interaction markers in Persian as compared to English. The significant interaction markers in both texts were hedges and boosters with high frequency. The research also suggested that the rhetorical system of Persian is different from the rhetorical system of English as far as the text of sociology is concerned. Marandi (2003) conducted contrastive analysis of English and Persian texts and highlighted the similarities and difference of interaction markers among these writers. A corpus was designed that comprised 19 research articles from English and Persian and the articles were taken from recognized journals. Z-test was used to see the difference between the interaction markers of both languages. The research showed that interaction markers are present in both languages, but the writers of English used more and more interaction markers.

Another interlingual study was conducted by Sultan (2011) to analyze the differences between the researchers of Native English and Arabic. The corpus for this contrastive study was taken from international academic journals restricted to eight years period from 2002 to 2009 from the field of linguistics. 70 research articles from native English writers and Arabic writers were taken and the portion of data discussion was analyzed to see the differences of interaction markers. Chi square test was used to see the differences of interaction markers. The results revealed that other than self-mentions, all the interaction markers were frequent in number in Arabic research writers of English. The research proved that the Arab writers pay excessive attention to the formal aspects of the text.

Salek and Yazdanimoghaddam (2014) in their study compared three set of corpora consisting of published research papers i.e. native English writers (NE), native Persian writers (NP) and non-native English writers (NNE) and analyzed the interaction markers. The researchers aimed to find out the difference of cultures of both English and Persian writers and the effect of English on the NNE research writers of English in Iran by seeing the metadiscourse features of the corpus. Hylands (2004) taxonomy of metadiscourse markers was used to analyze the interaction markers. The researchers employed chi square test to explore the differences between the corpora. The results revealed that non-native English research article writers used interaction markers most frequently with 1018 interaction markers. All the interaction markers were used significantly in (NNE) corpora. On the other hand, native English and native Persian writers of research articles had minor difference of the frequencies of interaction markers in corpora. The most occurring interaction markers were hedges in three set of corpora. Native Persian research article writers used least interaction markers while non-native English research article writers used interaction markers most frequently. Hence the results concluded by researchers suggested that the number of metadiscourse markers depend on writer's culture as proved in Spanish, Italian and Finish.

\section{Research Approach and Paradigm}

The research methodology is corpus-based mixed methods. The interactional metadiscourse devices are traced from corpus by using corpus-based approach. A corpus-based study initiates from a strong theoretical grounding and a corpus to confirm the theory and its implementations (Tognini-Bonelli, 2001). The extracted metadiscursive devices are quantified and then explained qualitatively to support the quantified data. In this research, interactive and interactional model of metadiscourse is employed which has been suggested by Hyland and Tse (2004a).

\subsection{Corpus Building and Design}

For the comparative analysis of the research, data are taken from 100 native English and Pakistani articles belonging to the fields of Linguistics, Literature, Sociology, Psychology and Management Sciences. The data for native English research writers are taken from Sciencedirect (http://www.sciencedirect.com) whereas Pakistani learners' research data are taken from HEC digital library (http://www.digitallibraray.edu.pk). Twenty articles from five different fields were taken for each set of corpora in this comparative study. The articles published from 2007 to 2017 were taken for corpus building by the researchers. The corpus is designed from the three sections of every research article i.e., abstract, data analysis and conclusion.

\subsection{Rationale for Sample Selection}

The data have been taken for the analysis following a criterion i.e., representativeness, reputation and accessibility. The taken data represents the whole as the selected NE and PE research articles represent all the research-based articles of Pakistani English and Native English. The corpus taken as a sample has good reputation as all the research articles are written by MS or PhD scholars having a good proficiency level. The third criterion is accessibility which suggests that the data should be accessible for the corpus building as well as for the analysis. Additionally, the reason for taking only abstract, discussion and conclusion portion of these 
articles is that the research writers try to structure the relationship and try to convince the readers towards their standpoint in these sections.

\subsection{Data Screening and Filing of Corpus}

The articles belonging to five different fields are downloaded from the websites in pdf files for both set of corpora. Ads and notes were removed to make only selective data analyzable in the software. Further, only three portions of each research article are taken i.e., abstract, data analysis and discussion and conclusion. While filing the corpus, the data are saved in Notepad files with .txt formatting. The two set of corpora are made to save the files belonging to the five disciplines separately. Each set of corpora contains 100 files which are analyzed for data analysis.

\subsection{Research Tool}

Antconc 3.2.4w (2011) and Udru dost keyboard are the two research tools that are used in this research. Antconc is a corpus analysis toolkit used for the text analysis. This is a program designed by Laurence Antony for the text analysis of the corpus (Antony, 2005). It contains a wide-ranging set of tools like word/keyword frequency generators, an authentic concordancer, tools for cluster analysis and lexical bundle analysis, and a word distribution plot (Antony, 2005). Antconc reveals the frequencies of the metadiscourse markers which are statistically analysed and quantified for the analysis in the light of theoretical framework. Both the softwares are used by the researchers as they are the best suited softwares for this study. Additionally, both the softwares are available on internet free of cost.

\subsection{Theoretical Framework}

Various taxonomies about metadiscourse have been presented with different views but undoubtedly, every scientific theory has some advantages and disadvantages through the time. Some linguists (Adel, 2006; Hyland, 2005a; Kopple, 1987; Crismore, 1981) have worked to improve and change the existing taxonomies of metadiscourse. Hyland and Tse (2004a) have offered a recent taxonomy of metadiscourse. It shows the classification of metadiscourse markers as interactive recourses and interactional recourses. Interactive markers are composed of frame markers, endophoric markers, transitions, evidential and code glosses while interactional markers are made up of attitude markers, self-mentions, hedges, engagement markers and boosters. By employing these interactive and interactional markers, professional and research writers create and develop a proper balance between topic-based discourse and human-face discourse (Hyland, 2005b).

\begin{tabular}{|c|c|c|}
\hline Category & Function & Examples \\
\hline Interactive resources & \multicolumn{2}{|c|}{ Help to guide reader through the text } \\
\hline Transitions & $\begin{array}{l}\text { express semantic } \\
\text { relation between main } \\
\text { clauses }\end{array}$ & $\begin{array}{l}\text { in addition/but/thus/ } \\
\text { and }\end{array}$ \\
\hline Frame markers & $\begin{array}{l}\text { refer to discourse acts, } \\
\text { sequences, or text } \\
\text { stages }\end{array}$ & $\begin{array}{l}\text { finally/to conclude/my } \\
\text { purpose here is to }\end{array}$ \\
\hline Endophoric markers & $\begin{array}{l}\text { refer to information in } \\
\text { other parts of the text }\end{array}$ & $\begin{array}{l}\text { noted above/see Fig/in } \\
\text { section } 2\end{array}$ \\
\hline Evidentials & $\begin{array}{l}\text { refer to source of } \\
\text { information from other } \\
\text { texts }\end{array}$ & $\begin{array}{l}\text { according to } X /(Y, \\
1990) / Z \text { states }\end{array}$ \\
\hline Code glosses & $\begin{array}{l}\text { help readers grasp } \\
\text { functions of ideational } \\
\text { material }\end{array}$ & $\begin{array}{l}\text { namely/e.g./such as/in } \\
\text { other words }\end{array}$ \\
\hline
\end{tabular}


Interactional resources Involve the reader in the argument

\begin{tabular}{|c|c|c|}
\hline Hedges & $\begin{array}{l}\text { withhold writer's full } \\
\text { commitment to } \\
\text { proposition }\end{array}$ & $\begin{array}{l}\text { might/perhaps/possible } \\
\text { about }\end{array}$ \\
\hline Boosters & $\begin{array}{l}\text { emphasize force or } \\
\text { writer's certainty in } \\
\text { proposition }\end{array}$ & $\begin{array}{l}\text { in fact/definitely/it is } \\
\text { clear that }\end{array}$ \\
\hline Attitude markers & $\begin{array}{l}\text { express writer's } \\
\text { attitude to proposition }\end{array}$ & $\begin{array}{l}\text { unfortunately/I agree/ } \\
\text { surprisingly }\end{array}$ \\
\hline Engagement markers & $\begin{array}{l}\text { explicitly refer to or } \\
\text { build relationship with } \\
\text { reader }\end{array}$ & $\begin{array}{l}\text { consider/note that/you } \\
\text { can see that }\end{array}$ \\
\hline Self-mentions & $\begin{array}{l}\text { explicit reference to } \\
\text { author(s) }\end{array}$ & I/we/my/our \\
\hline
\end{tabular}

Figure 1. Hyland and Tse (2004a) model of academic metadiscourse

\section{Data Analysis and Discussion}

The research articles written by Pakistani writers are notably shorter than English writers regarding word count. The three portions of each research articles i.e., abstract, data analysis and discussion and conclusion are taken for corpus building. The instances of interactive and interactional markers are typed in search bar of Antconc and their frequencies are quantified to present the statistical data in the form of graph.

\subsection{Interactive Markers}

\subsubsection{Transitions}

We will be involved more than currently. $\underline{\text { Similarly, }}$, another director commented....

The researcher in this example uses a transition marker which is meant to link together two clauses or sentences. Here, similarly is linking together two clauses in order to add semantic meanings and cohesion. The other transition found in corpus are however, yet, whereas, so, also etc.

\subsubsection{Frame Markers}

$\underline{\text { First }}$, he wrote according to his testimony, from that city. $\underline{\text { Second }}$, he ......

The example shows two frame markers extracted from research articles which refer to the text stages, explaining about a phenomenon and guiding the readers through the text (Hyland \& Tse, 2004a). The corpus exhibits other frame markers such as in addition, in brief, to sum up, overall etc.

\subsubsection{Endophoric Markers}

For example, Figure 2 highlights the relationship between hypertension and working hours...

The function of endophoric markers is to guide the readers by using text while referring to the other parts in the discussion. For instance, the relationship between text and figure is drawn by the writer with help of an endophoric marker (Hyland, 2005b). The other extracted examples are figure $\mathrm{x}$, In this section, for example etc.

\subsubsection{Evidentials}

According to Freud, the viewpoint of the child towards the senior in the family......

Evidentials are a common part of research writing (Hyland, 2005b). The writers refer some other information or text in their writing by using evidential markers as evident in the example. The writer in this analogy refers to some other text which guides the readers. Some of the examples revealed in the corpus are cites by X, X states, Reference, year etc.

\subsubsection{Code Glosses}

What has become an identifiable area of work called management and a corresponding body of work called management theory. 
The above given analogy is the example of code glosses which are the metadiscourse markers practiced by the authors in order to refer to an ideational conception. For instance, the traced examples are defined as, which means, suggest, namely etc.

\subsection{Interactional Markers}

\subsubsection{Hedges}

He claims as legatee of Mr. Underwood, if she survived ....

In the above given example, the writer withholds the commitment to the proposition and gives his readers a chance either to accept or reject the writer's statement (Hyland, 2005a). The markers like hedges involve the readers in the text and allow them to make their own point of view about the discussed idea. The examples taken from corpus are about, appear, indicate, I feel, I believe etc.

\subsubsection{Boosters}

The thinking patterns are $\underline{\text { no doubt }}$ the same in this case as well...

The boosters, contrary to hedges are the metadiscourse markers which imply the certainty of the author's proposition and the reader is given no chance to dispute the judgments of the author. The metadiscourse marker 'no doubt' is evident as booster in the example. The other boosters found in corpus are definitely, surely, truly, never, must etc.

\subsubsection{Attitude Markers}

Surprisingly, the market value of the bit coin increased $42 \%$ in last two years...

The metadiscourse marker 'surprisingly' involves the readers in the text by sharing the attitude of the writer towards a judgement and named as attitude marker (Hyland, 2005a). The markers like unexpected, unbelievable, disagree, hopefully etc.

\subsubsection{Self-Mentions}

$\underline{T}$ The rearcher tries to explore the psychological factors involved in criminal activities...

The example shows an instance of self-mention where the writer himself is referred in the text in order to involve and engage the readers to the opinion and viewpoint of the author. Here, 'the researcher' serves as a self-mention. Other than the researcher, 'I and my' are the prominent self-mentions in the corpus.

\subsubsection{Engagement Markers}

Table 1. Metadiscourse markers in native English research writing

\begin{tabular}{ll}
\hline $\begin{array}{l}\text { Interactive } \\
\text { Interactional }\end{array}$ & \\
\hline Transitions & 2180 \\
Frame markers & 3015 \\
Endophoric markers & 351 \\
Evidentials & 1846 \\
Code Glosses & 1557 \\
Total & 8949 \\
Hedges & 2453 \\
Boosters & 2890 \\
Attitude markers & 557 \\
Self-Mentions & 187 \\
Engagement markers & 2742 \\
Total & 8829 \\
Grand Total & 17778 \\
\hline
\end{tabular}

$\underline{\text { Let } \boldsymbol{U S}}$ see an example of how the proposed system works in practice....

The example exhibits an engagement marker which is used to build a rapport and a relationship between the writer and the readers. Such engagement markers are employed in a text in order to involve the readers into the text to make them understand the viewpoint. Add, should, we, us, consider etc. are the engagement markers present in the corpus. 
Table 2. Metadiscourse markers in Pakistani English research writing

\begin{tabular}{ll}
\hline Interactive \\
Interactional
\end{tabular}

\subsection{Interactive Markers in NE and PE Corpus}

Figure 2 represents the quantification of interactive markers in native English and Pakistani English research writings. The corpus results reveal that Pakistani academic research writers guide their readers more and more with the help of text. It is evident that all the interactive markers are higher in frequency in the writings of Pakistani researchers as compared to native English authors except in the case of frame markers. The frequency of frame makers is highest among all the interactive markers of English as well as Pakistani research writers. Another significant difference can be seen in comparison of endophoric markers in two corpora which implies that the Pakistani research writers infer the other parts of the article more contrary to native English writers, in order to guide the readers. These markers are used with high frequency by Pakistani research writers. The overall quantification illustrates that every 111th word is an interactive marker in native English research articles whereas every 95th word is an interactive marker in Pakistani research articles which suggests that the Pakistani research writers guide the readers to towards their proposition effectively.

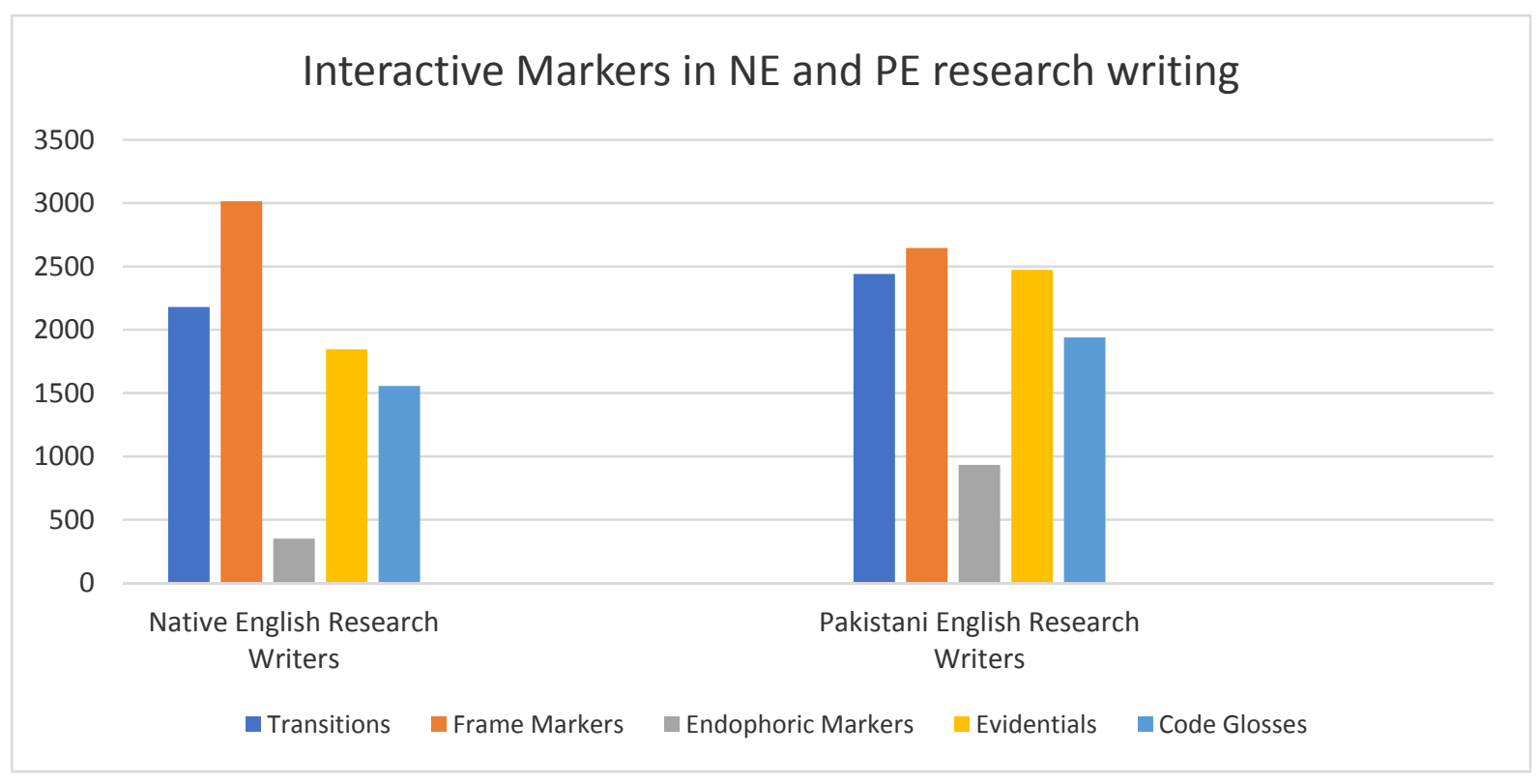

Figure 2. Interactive markers in NE and PE research writing 


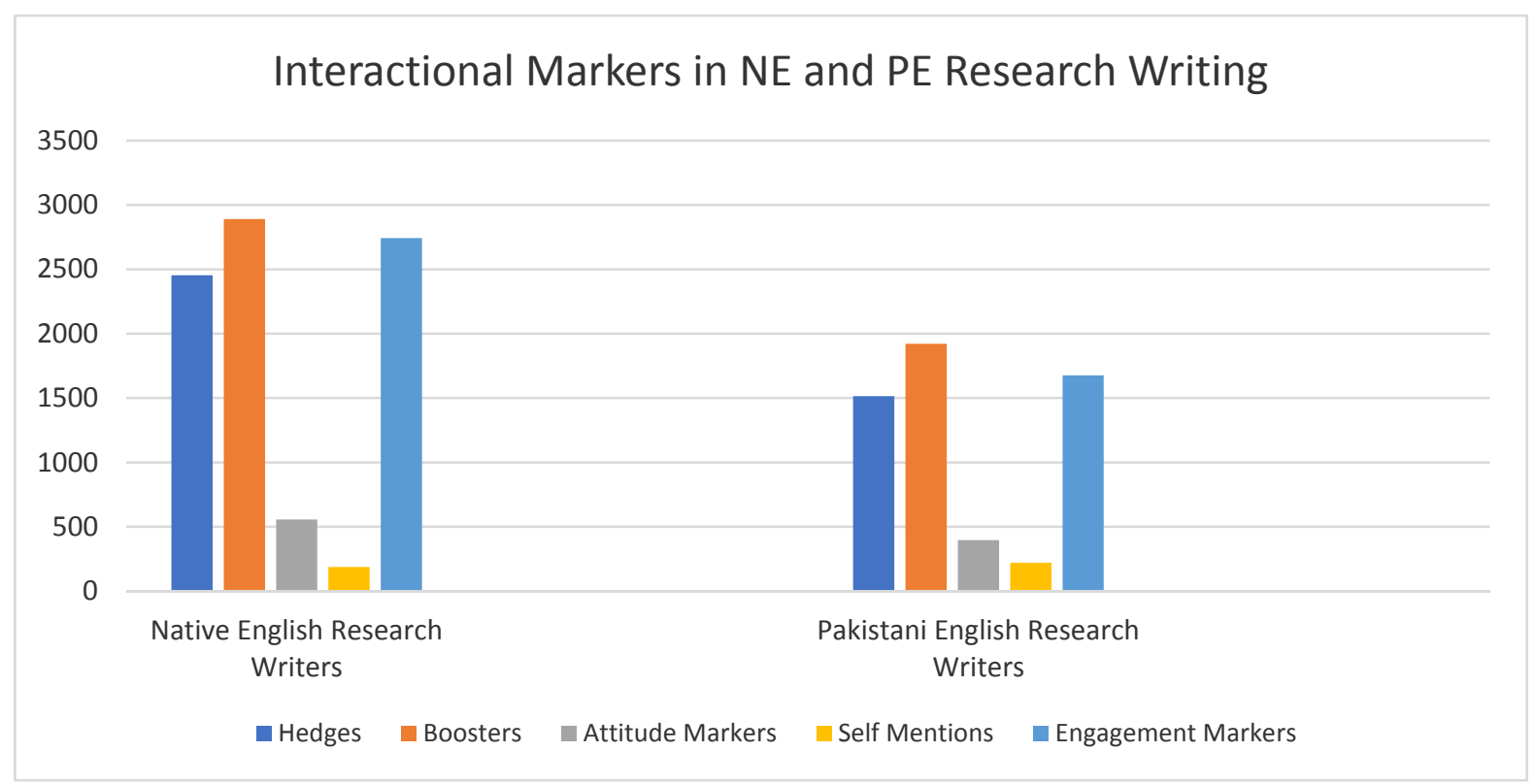

Figure 3. Interactional markers in NE and PE research writing

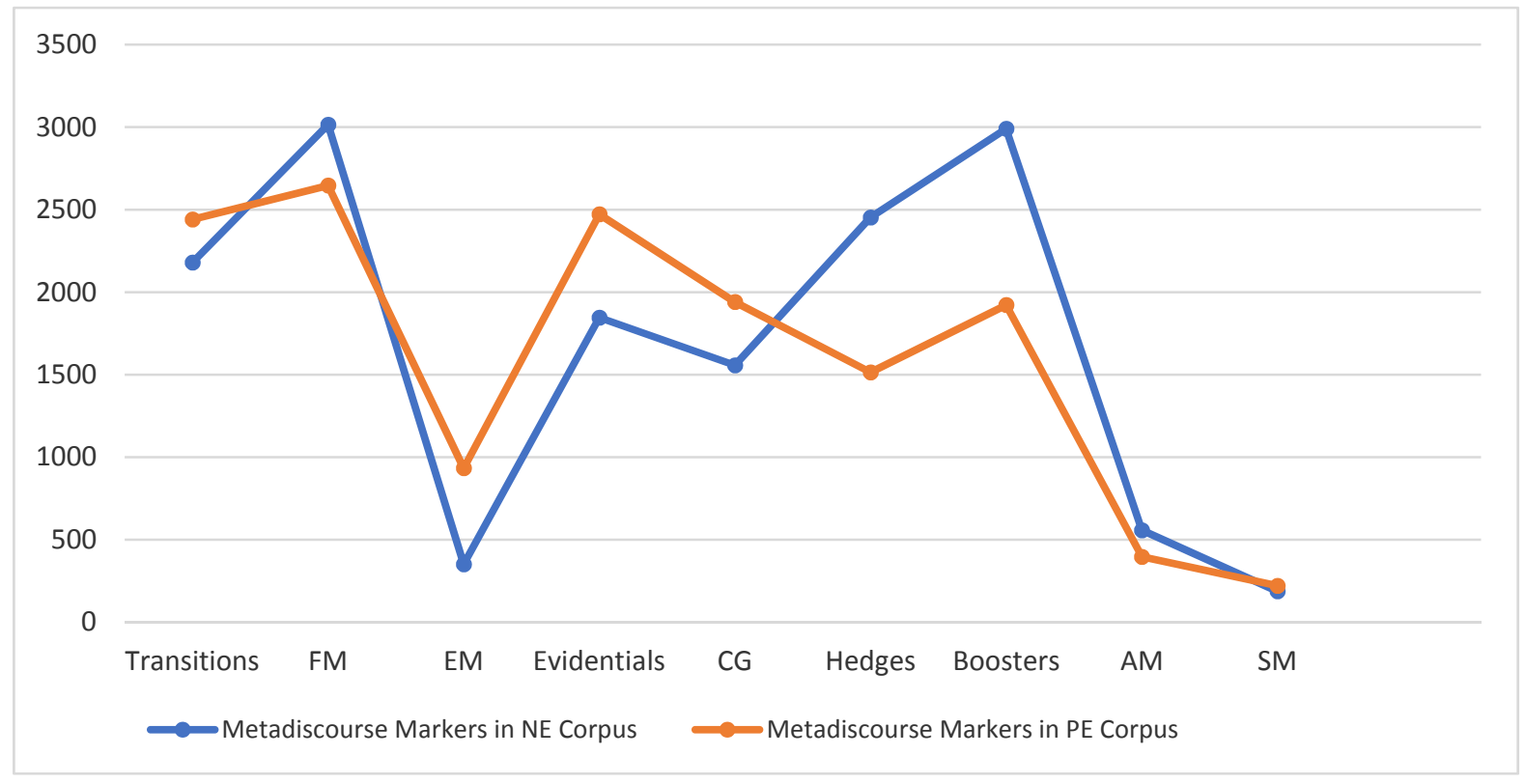

Figure 4. Metadiscourse markers in NE and PE research writing

\section{Conclusion}

This research article is an attempt to compare Native English and Pakistani English research writings in the employment of metadiscourse markers i.e. interactive markers and interactional markers and the results show that the norms of both research writers are different in some ways. The quantitative analysis exhibits that interactive markers are frequent in PE research writing as compared to NE research writing which suggests that by applying various interactive markers such as transitions, frame markers, and code glosses, the PE research writers enhance the clarity and comprehensibility of texts for the audience which can minimize the efforts of the readers to understand text in a better way. All the interactive markers are higher in number except frame markers which includes the markers like firstly, subsequently, to summarize and at this point. Moreover, evidentials are present in significant number that implies that Pakistani research writers are more likely to guide the audience 
through text by using markers which are the reference to another text. In contrary, interactional metadiscourse markers are higher in frequency, individually as well as on the whole in NE corpora as compared to PE corpora, which suggests that NE research writers involve the audience more effectively in their proposition and argumentation. Here, the most considerable interactional marker is booster which helps the authors to convey their viewpoint with authenticity. The accumulative quantitative results infer that NE research writing is more convincing, credible and resounding as the frequency of metadiscourse markers is higher in NE research writing in contrast with PE research writing.

\section{References}

Abdi, R. (2011). Metadiscourse strategies in research articles; A study of the differences across subsections. Journal of Teaching Language Skills, 3(1), 1-16. http://jtls.shirazu.ac.ir/article_391.html

Abdollahzadeh, E. (2003). Interpersonal metadiscourse in ELT papers by Iranian and Anglo-American academic writers. In international conference on multiculturalism in ELT practice at Baskent University, Turkey.

Abdollahzadeh, E. (2010). Undergraduate Iranian EFL learners' use of writing strategies. Writing \& Pedagogy, 2(1), 65-90. https://doi.org/10.1558/wap.v2i1.65

Ädel, A. (2006). Metadiscourse in L1 and L2 English (Vol. 24). John Benjamins Publishing. https://doi.org/10.1075/scl.24

Anthony, L. (2005). (2005). AntConc: Design and Development of Freeware Corpus Analysis Toolkit for the Technical Writing Classroom (pp. 729-737). In IEEE International Professional Conference Proceedings.

Attarn, A. (2014). Study of metadiscourse in ESP articles: A comparison of English articles written by Iranian and English native speakers. International Journal of Learning, Teaching and Educational Research, 5(1), 63-71. https://www.ijlter.org/index.php/ijlter/article/view/87

Beauvais, P. J. (1989). A speech act theory of metadiscourse. Written Communication, 6(1), 11-30. https://doi.org/10.1177/0741088389006001002

Behzad, A., \& Shafique, H. (2018). Certainty/uncertainty as an important trait of authorship: A linguistic analysis of Urdu newspaper discourse (Mayar-vol-18). Retrieved from https://www.iiu.edu.pk/wp-content/uploads/downloads/journals/mayar/articles-wise/Meyar-18-2017/23.pdf

Breivega, K., Dahl, T., \& Fløttum, K. (2002). Traces of self and others in research articles. A comparative pilot study of English, French and Norwegian research articles in medicine, economics and linguistics. International Journal of Applied Linguistics, 12(2), 218-239. https://doi.org/10.1111/1473-4192.00032

Casanave, C. P. (2003). Multiple uses of applied linguistics literature in a multidisciplinary graduate EAP class. ELT Journal, 57(1), 43-50. https://doi.org/10.1093/elt/57.1.43

Crismore, A. (1989). Talking with readers: Metadiscourse as rhetorical act. New York: Peter Lang Publishers.

Flowerdew, J. (1999). Description and interpretation in critical discourse analysis. Journal of Pragmatics, 31(8), 1089-1099. https://doi.org/10.1016/S0378-2166(99)00049-1

Gray, J. (2000). The English coursebook as cultural artifact: How teachers censor and adapt. EFL Journal, 54, 3. https://doi.org/10.1093/elt/54.3.274

Halliday, M. A. K. (1994). An introduction to functional grammar. London: Edward Arnold.

Hyland, K. (2004). Disciplinary discourses, Michigan classics ed.: Social interactions in academic writing. University of Michigan Press. https://doi.org/10.3998/mpub.6719

Hyland, K. (2005a). Metadiscourse: Exploring Interaction in Writing. London: Continuum. https://www.elixirpublishers.com/articles/1350120089_40\%20(2011)\%205245-5250.pdf

Hyland, K. (2005b). Metadiscourse: Mapping Interaction in Academic Writing. University of London, UK http://ojs.ub.gu.se/ojs/index.php/njes/article/view/417

Hyland, K., \& Tse, P. (2004). Metadiscourse in academic writing: A reappraisal. Applied Linguistics, 25(2), 156177. https://doi.org/10.1093/applin/25.2.156

Lautamatti, L. (1978). Observations on the development of the topic in simplified discourse. A FinLAn vuosikirja, $71-104$

Marandi, S. (2002). Contrastive EAP rhetoric: metadiscourse in Persian versus English. Unpublished doctoral dissertation, University of Tehran, Tehran. 
Mauranen, A. (1993b). Cultural Differences in Academic Rhetoric. Frankfurt: Peter Lang.

Rahimpour, S. (2006). Contrastive rhetoric of English and Persian texts; metadiscourse in applied linguistics research articles. Unpublished Master's thesis, University of Mashad. http://citeseerx.ist.psu.edu/viewdoc/download?doi=10.1.1.542.1292\&rep=rep1\&type=pdf

Schiffrin, D. (1980). Meta - talk: Organizational and evaluative brackets in discourse. Sociological Inquiry, 50(3-4), 199-236. https://doi.org/10.1111/j.1475-682X.1980.tb00021.x

Shafique, H. (2016). A contrastive analysis of interaction markers in journalistic writings of English and Urdu: A corpus-based study. Unpublished, University of Gujrat.

Shahbaz, M., \& Liu, Y. B. (2012). Complexity of L2 Motivation in an Asian ESL Context. Porta Linguarum, 18, $115-132$.

Shahbaz, M., Sheikh, O. I., \& Shahbaz Ali, M. (2013). Use of discourse markers by Chinese EFL professors: A corpus-based study of academic lectures by natives and non-natives. Journal of Education and Practice, $4(5), 80-89$.

Shokouhi, H., \& Baghsiahi, A. T. (2009). Metadiscourse functions in English and Persian sociology articles: A study in contrastive rhetoric. Poznań Studies in Contemporary Linguistics, 45(4), 549-568. https://doi.org/10.2478/v10010-009-0026-2

Sultan, A. H. (2011). A contrastive study of metadiscourse in English and Arabic linguistics research articles. Acta Linguistica, 5(1), 28. http://www.actalinguistica.com/arhiv/index.php/als/article/view/354

Taki, S., \& Jafarpour, F. (2012). Engagement and stance in academic writing: A study of English and Persian research articles. Mediterranean Journal of Social Sciences, 3(1), 157-168.

Tajeddin, Z., \& Yazdanmehr, E. (2013). Investigating the structural patterns and pragmatic functions of compliments made by Iranian EFL learners. Journal of English Language Teaching and Learning, 4(10), $27-51$.

Tognini-Bonelli, E. (2001). Corpus linguistics at work (Vol. 6). John Benjamins Publishing. https://doi.org/10.1075/scl.6

Valero-Garces, C. (1996). Contrastive ESP rhetoric: metatext in Spanish-English Economics texts. English for Specific Purposes, 15(4), 279-294. https://doi.org/10.1016/S0889-4906(96)00013-0

Vassileva, I. (2001). Commitment and detachment in English and Bulgarian academic writing. English for Specific Purposes, 20(1), 83-102. https://doi.org/10.1016/S0889-4906(99)00029-0

Williams, J. (1981). Style: Ten lessons in clarity and grace (pp. 22-23). Scott, Foresman.

Yazdanimoghaddam, M., \& Salek, M. (2014). Study of English and Persian Thought Patterns through Metadiscourse Strategies. The Iranian EFL Journal, 10(3), 345-359.

\section{Copyrights}

Copyright for this article is retained by the author, with first publication rights granted to the journal.

This is an open-access article distributed under the terms and conditions of the Creative Commons Attribution license (http://creativecommons.org/licenses/by/4.0/). 